\title{
Republic of Montenegro: Financial System Stability Assessment
}

This Financial System Stability Assessment paper for the Republic of Montenegro was prepared by a staff team of the International Monetary Fund as background documentation for the periodic consultation with the member country. It is based on the information available at the time it was completed on December 18, 2007. The views expressed in this document are those of the staff team and do not necessarily reflect the views of the government of the Republic of Montenegro or the Executive Board of the IMF.

The policy of publication of staff reports and other documents by the IMF allows for the deletion of market-sensitive information.

To assist the IMF in evaluating the publication policy, reader comments are invited and may be sent by e-mail to publicationpolicy@imf.org.

Copies of this report are available to the public from International Monetary Fund • Publication Services

700 19th Street, N.W. • Washington, D.C. 20431

Telephone: (202) 6237430 • Telefax: (202) 6237201

E-mail: publications@imf.org • Internet: http://www.imf.org

Price: $\$ 18.00$ a copy

\section{International Monetary Fund Washington, D.C.}





\title{
INTERNATIONAL MONETARY FUND
}

\author{
REPUBLIC OF MONTENEGRO
}

\section{Financial System Stability Assessment}

\author{
Prepared by the Monetary and Capital Markets and European Departments \\ Approved by Christopher Towe and Michael Deppler
}

December 18, 2007

This Financial System Stability Assessment (FSSA) is based on the work of the joint IMF/World Bank Financial Sector Assessment Program (FSAP) mission that visited Podgorica in July, September, and October 2006. The data have been updated to the extent possible.

The FSAP team comprised Messrs. Fernando Montes-Negret (Mission Head, World Bank), Michael Edwards, Peter Kyle, Ms. Sonja Brajovic-Bratanovic (all World Bank); Messrs. Karl Driessen (Mission Head, IMF), Magnus Alvesson, Harald Hirschhofer, Ms. Elena Duggar (all IMF), Messrs. Alfredo Bello, Ronald MacDonald, Tyge Rasmussen, and Walter Zunic (experts). The FSAP team received excellent cooperation from the authorities. The main findings of the FSAP are:

- Montenegro is experiencing a credit boom that is primarily funded by local deposit growth. Until recently, lending growth was concentrated in the largest bank, recently sold to a rated foreign banking group. However, other banks are now engaged in rapid expansion, posing supervisory challenges and increasing macroeconomic risk.

- There is scope for further reducing the role of the public sector in the financial system. This includes gradually moving public deposits from commercial banks to the Central Bank of Montenegro (CBM), limiting the growth in funding for further credit expansion and reducing governance issues.

- It is important to strengthen the legal framework, including the adoption of the draft Law on Banks and enhancing enforcement powers. Although the overall quality of banking supervision was found to be robust, enforcement powers are insufficient.

- A correction of the stock market may pose a reputational risk to the young financial system; the authorities are encouraged to increase disclosure requirements, commence investigations into suspicious transactions, and strengthen enforcement.

Since the FSAP missions, credit growth has accelerated further, and associated vulnerabilities have increased. This report was prepared by Karl Driessen, based on the work of the FSAP team.

FSAPs are designed to assess the stability of the financial system as a whole and not that of individual institutions. They have been developed to help countries identify and remedy weaknesses in their financial sector structure, thereby enhancing their resilience to macroeconomic shocks and cross-border contagion. FSAPs do not cover risks that are specific to individual institutions such as asset quality, operational or legal risks, or fraud. 
Glossary 3

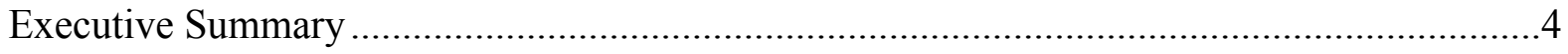

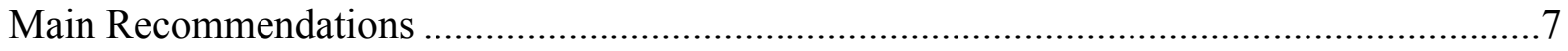

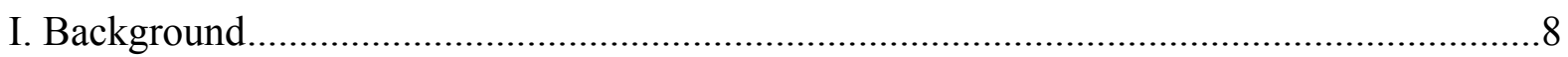

II. Key Financial Sector Risks and Vulnerabilities................................................ 11

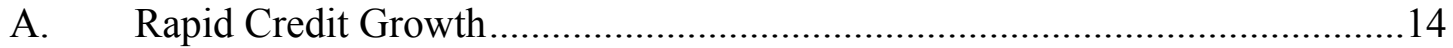

B. Vulnerabilities Associated with Unilateral Euroization ...............................15

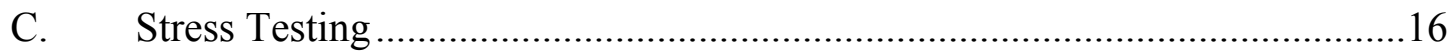

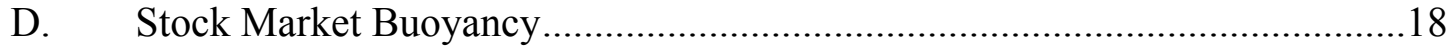

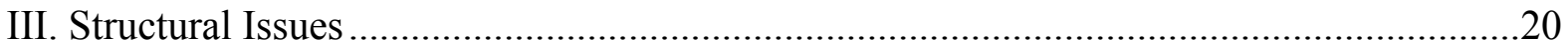

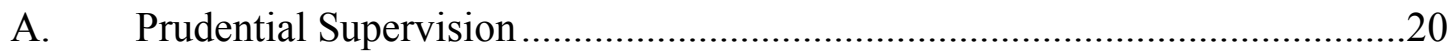

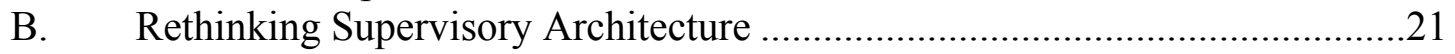

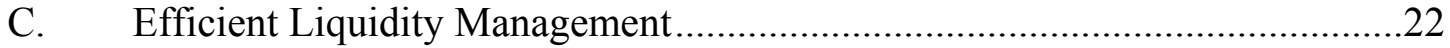

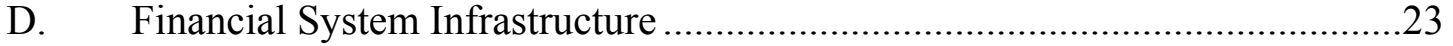

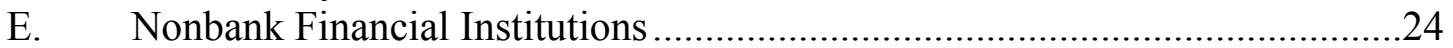

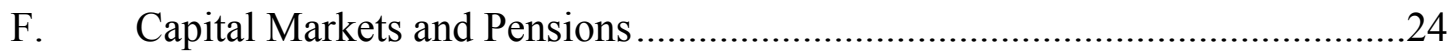

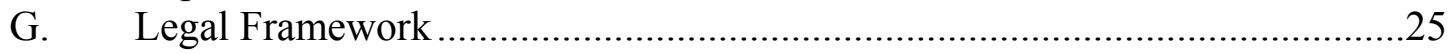

H. Anti-Money Laundering and Combating the Financing of Terrorism.............26

Appendices

I. Observance of Financial Sector Standards and Codes - Summary Assessment................28

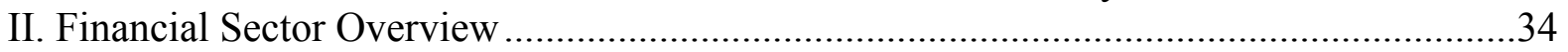

Tables

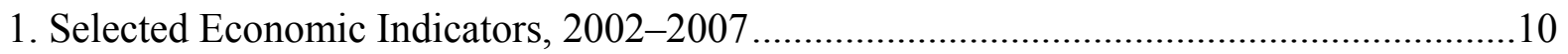

2. Structure of the Financial System, 2002-2006 .................................................................. 12

3. Financial Soundness Indicators of the Banking Sector, 2004-2007.................................13

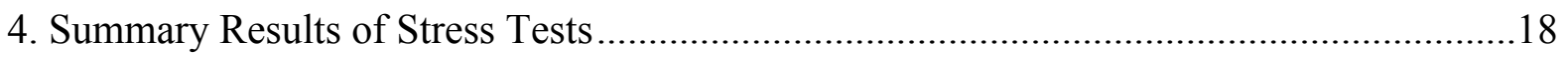

Figures

1. Developments in Financial Sector ...............................................................................

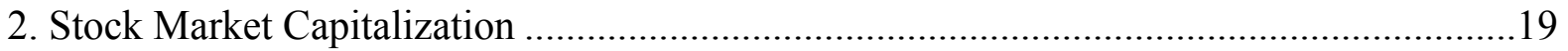

Appendix Table

5. Recommended Action Plan to Improve Compliance of the Basel Core Principles 


\section{GLOSSARY}

$\begin{array}{ll}\text { AML/CFT } & \text { Anti-Money Laundering/Countering the Financing of Terrorism } \\ \text { BCP } & \text { Basel Core Principles } \\ \text { CAR } & \text { Capital Adequacy Ratio } \\ \text { CBM } & \text { Central Bank of Montenegro } \\ \text { CDA } & \text { Central Depository Agency } \\ \text { CKB } & \text { Crnogorska Komercijalna Banka } \\ \text { ECB } & \text { European Central Bank } \\ \text { EU } & \text { European Union } \\ \text { FSAP } & \text { Financial Sector Assessment Program } \\ \text { GDP } & \text { Gross Domestic Product } \\ \text { IFRS } & \text { International Financial Reporting Standards } \\ \text { IOSCO } & \text { International Organization of Securities Commissions } \\ \text { LOB } & \text { Law on Banking } \\ \text { MFI } & \text { Micro Finance Institution } \\ \text { MoF } & \text { Ministry of Finance } \\ \text { MONEYVAL } & \text { Committee of Experts on the Evaluation of Anti-Money Laundering } \\ \text { MTPL } & \text { Measures } \\ \text { NBFI } & \text { Motor Third-Party Liability } \\ \text { NEX } & \text { Nonbank Financial Institution } \\ \text { NLB } & \text { New Exchange Montenegro } \\ \text { NPLs } & \text { Nova Ljubljanska Bank } \\ \text { SEC } & \text { Nonperforming Loans } \\ & \text { Securities and Exchange Commission } \\ \end{array}$




\section{EXECUTIVE SUMMARY}

Montenegro, like many other countries in the region, is undergoing rapid credit growth, in the context of heavy foreign bank presence and euro use. To some extent, this credit growth represents a catch-up phenomenon from a low base, and the presence of foreign bank subsidiaries has been stabilizing, providing risk management expertise, as well as capital and liquidity support. Moreover, the euro has helped provide a stable macroeconomic environment - including low-interest rates — conducive for financial development.

However, the rate of credit expansion is testing the limits of banks' capacity to underwrite loans prudently and maintain adequate buffers. Credit outstanding more than doubled in 2006, and this trend accelerated in 2007, with year-on-year growth as of endSeptember 2007 at 177 percent. Some banks have exceeded this rate substantially, and vigorous competition has put pressure on profitability. Worrisomely, the quality of information about borrowers is limited, and banks' internal control systems are weak. Although nonperforming loans are at a low level, these are lagging indicators and do not present an accurate picture of loan quality in times of rapid loan growth. Indicators of bank liquidity are decreasing. Moreover, there are signs that rapid credit growth is leading to macroeconomic overheating.

Rapid credit growth is now also posing supervisory challenges, despite relatively strong financial sector regulation and supervision. Until mid-2006, credit growth was concentrated in one large bank, but more recently other banks have experienced triple-digit lending growth, forcing supervisory resources to be spread more thinly.

There are a number of considerations that are relevant in assessing the degree of risk and vulnerability in Montenegro:

- On the positive side, funding for credit growth in Montenegro comes mostly from asset sales to non-residents, including coastal real estate sales. The continued formalization of the economy has also contributed to increased bank funding. This is in contrast to other countries in the region that have relied in large part on potentially more volatile foreign bank lending to finance their credit booms.

- $\quad$ Not all foreign-owned banks in Montenegro can count on well-capitalized and liquid parent institutions. Although the quality of foreign ownership has improved recently with the purchase of a major bank by Hungarian OTP Group, the share of bank assets owned by rated financial institutions is declining.

- Unilateral euroization creates more exposure to liquidity risk than eurozone members. The use of the euro predates Montenegro's recent independence and has provided a foundation for the development of the financial system. As in other countries that use the euro, the inability to adjust the nominal exchange rate makes adjustment in competitiveness more difficult. However, since Montenegro is not part 
of the eurozone, the Central Bank of Montenegro (CBM) can perform only a limited lender-of-last-resort function in the face of liquidity shocks to the banking system.

- Public sector bank deposits and lending are still significant and concentrated despite a sharp reduction in direct state ownership. These deposits have played an important role in funding the credit boom, and the public sector's close and selective involvement with commercial banks have given rise to governance, transparency, and risk management-related concerns.

- A significant correction in stock market prices is underway, and ongoing volatility may pose a risk for the young financial system. The market had been extremely buoyant in recent years (market indices rose by over 300 percent during the 12 months to end-April 2007, before coming down about 40 percent). Financial reporting requirements for traded firms are weak. Although banks' exposure to the stock market is modest, high yields were providing incentives for bank customers to invest in the stock market, including using "cash" loans provided by banks on the basis of salary deposits.

- As a small country, Montenegro faces a high fixed-cost disadvantage to establishing a low-cost operating environment for its financial system. This has implications for the organization of financial supervision as well as the market structure of the financial sector.

The recommended policy response is a mix of prudential strengthening-to address risks emanating from rapid credit growth-and measures to address specific vulnerabilities:

- Prudential aspects of rapid credit growth should be addressed by a multipronged strategy that relies on actions by banks, supervisors, and the legislative branch. Banks must be encouraged to strengthen internal processes and controls. The supervisor needs to continuously re-evaluate the range of bank risk management practices, prepare bank-by-bank responses, and strengthen the existing regulatory framework, including the liquidity regulation. Home-host supervisory coordination should be strengthened in light of the importance of foreign bank ownership, and of the adoption of Basel II that may amplify differences in regulatory environments. Credit registry access should be broadened to facilitate banks' risk management.

- The Law on Banking should be adopted, and supervisory enforcement strengthened. Once the Law is adopted, supervisors - including of non-bank institutions - would still lack enforcement powers common in other jurisdictions, and the authorities would need to work on (i) increasing legal protection for supervisors; (ii) empowering supervisors to impose appropriate remedial measures in individual situations; (iii) authorizing supervisors to impose monetary penalties directly without having to first obtain court approval; and (iv) enhancing the rights of appeal to administrative court decisions. In the stock market, the Securities and Exchange 
Commission should vigorously investigate suspicious trading, and build up a strong enforcement record.

- $\quad$ The public sector should gradually move most of its deposits from commercial banks to the CBM. Doing so would also be beneficial in establishing more armslength relations between banks and government-related agencies, while at the same time helping to sterilize the large capital inflows that are providing funding for the credit boom. The deposits should be remunerated appropriately by the CBM. The timeframe for shifting these deposits should be set with a view to allowing banks to adjust their balance sheets smoothly, and the deposits should be remunerated appropriately by the CBM.

- Efficiency considerations should inform supervisory and financial architecture, including the size of the CBM and other supervisory agencies. Pooling of scarce human resources and training could improve the effectiveness and quality of supervision. Establishing a common platform for the securities exchanges and interoperability in the electronic payment infrastructure would be beneficial for operational efficiency. 


\section{MAIN RECOMMENDATIONS}

\begin{tabular}{|c|c|}
\hline & Time Frame \\
\hline $\begin{array}{l}\text { Manage Growing Credit Risk } \\
\text { - } \quad \text { Adopt draft Law of Banks. } \uparrow 29 \\
\text { - } \quad \text { Tighten prudential supervision. } \uparrow \uparrow \mid 12,17,31\end{array}$ & $\begin{array}{l}\text { ST } \\
\text { ST }\end{array}$ \\
\hline $\begin{array}{l}\text { Reduce Public Role in Financial Sector } \\
\text { - } \quad \text { Gradually transfer public sector deposits to CBM. } ₫ 19 \\
\text { - } \quad \text { Public sector to operate at an arms-length basis to improve governance and risk management. } ₫ 19\end{array}$ & $\begin{array}{l}\text { ST/MT } \\
\text { ST }\end{array}$ \\
\hline $\begin{array}{l}\text { Liquidity Management Framework } \\
\text { - Use a single required reserve ratio; use liquidity ratio regulations for prudential purposes, while } \\
\text { reducing the reserve requirement gradually over time; remove option of holding required reserves } \\
\text { in treasury bills; gradually remove the limit of } 50 \text { percent on maximum usable reserves. } \uparrow \uparrow \mid 38-39 \\
\text { - Reference the interest rate on liquidity maintenance credits to the relevant ECB rate; abolish } \\
\text { interest charges for intraday credit and use automatic collateral system. } 940\end{array}$ & MT \\
\hline $\begin{array}{l}\text { Payment Systems } \\
\text { - Prepare and enact a Law on Payment and Settlement Systems. } \uparrow 41 \\
\text { - Start oversight of settlement and clearing systems for electronic payment instruments. } ₫ 42 \\
\text { - Provide leadership to develop national infrastructure for electronic payment instruments that } \\
\quad \text { allows for inter-operability of different platforms. } \uparrow 42\end{array}$ & $\begin{array}{l}\text { MT } \\
\text { ST } \\
\text { MT }\end{array}$ \\
\hline $\begin{array}{l}\text { Credit Registry } \\
\qquad \quad \text { Broaden access to credit registry. } \uparrow 12\end{array}$ & ST \\
\hline $\begin{array}{l}\text { Capital Markets } \\
\text { - Strengthen disclosure requirements and enforcement in securities market. } \uparrow 27 \\
\text { - Evaluate consequences in legislation, regulation and infrastructure of moving to an open market } \\
\text { allowing cross-border membership and off-exchange/OTC trading. } \uparrow 51 \\
\text { - Move both stock exchanges to one common trading platform. Reorganize market/listing } \\
\text { structure. } ₫ 49\end{array}$ & $\begin{array}{l}\text { ST } \\
\text { ST } \\
\text { MT }\end{array}$ \\
\hline $\begin{array}{l}\text { Legal Framework } \\
\text { - Provide legal protection for the CBM, its officers, staff and agents against liability for damages } \\
\text { caused by such persons in the good faith performance of their duties. } ₫ 53 \\
\text { - } \text { Empower supervisors to impose appropriate remedial measures in individual situations. } ₫ 53 \\
\text { - Authorize the supervisors to impose monetary penalties directly without having to first obtain } \\
\text { court approval. } \uparrow 53 \\
\text { - Create precedent in judicial handling of criminal cases including regarding insider trading and } \\
\text { other market abuses. } \llbracket 48\end{array}$ & $\begin{array}{l}\text { ST } \\
\text { ST } \\
\text { ST } \\
\text { ST }\end{array}$ \\
\hline
\end{tabular}




\section{BACKGROUND}

1. Montenegro declared independence on June 3, 2006, following an affirmative outcome of the referendum for independence on May 21. This small Balkan country, which joined the IMF and World Bank on January 18, 2007, is opening up rapidly to foreign investment, including in the financial sector. In the general elections, held on September 10, 2006, the pro-independence parties solidified their support in the electorate, continuing a reform-minded government.

2. The salient feature of the monetary framework is Montenegro's decision to use the euro without its central bank being a member of the European System of Central Banks. ${ }^{1}$ The Central Bank of Montenegro (CBM) is not authorized to issue currency and conducts no independent monetary policy_although at the margin it can affect local liquidity conditions by changing reserve requirements. The CBM may not grant loans to the government and does not have the authority to participate in the primary market for government securities.

3. Unilateral euroization has brought significant benefits-including the dramatic reduction in inflation witnessed when the dinar was abolished. Other benefits included reduced transaction costs and the elimination of the currency risk premium. These appear to have offset the costs associated with (i) ceding the ability to use monetary or exchange rate policy to cushion the economy against external shocks; (ii) strictly limiting the lender-of-lastresort functionality in the event of a banking crisis; (iii) loss of seigniorage revenue; and (iv) higher liquidity management costs.

4. Large capital inflows are fueling financial intermediation (Figure 1, Table 1). From around 30 percent of GDP in 2001, banking sector assets have risen to 72 percent in 2006 (Table 2). ${ }^{2}$ Over the period 2004-06, cumulative capital account inflows exceeded the current account deficit by 14 percent of GDP. Larger enterprises, such as aluminum producer KAP and tourism operators, have sought financing abroad, directly or through foreign-owned banks - total foreign bank borrowing at end-2006 amounted to EUR 156 million. There are signs that bank financing from abroad is increasing.

5. The fiscal stance, the sole remaining macroeconomic policy instrument, has been tightened. The fiscal balance before grants turned from an average deficit of 4.3 percent of GDP in 2002-04 to a surplus of 2.2 percent of GDP in 2006. Aided by Paris Club settlements, Montenegro's public debt has fallen by well over 40 percentage points of GDP to 38 percent of GDP at end-2006, and privatization proceeds are expected to lower the ratio further.

\footnotetext{
${ }^{1}$ This will be referred to as "unilateral euroization."

${ }^{2}$ In 2001, the aggregate banking sector's balance sheet included frozen FX savings and past due foreign debt that needed to be written off. Excluding these items, total assets to GDP ratio was about 20 percent.
} 
However, public debt could be affected by the on-going process of restitution of state-seized property, future pension liabilities, and contingent liabilities in state-owned enterprises.

Figure 1. Montenegro: Developments in Financial Sector
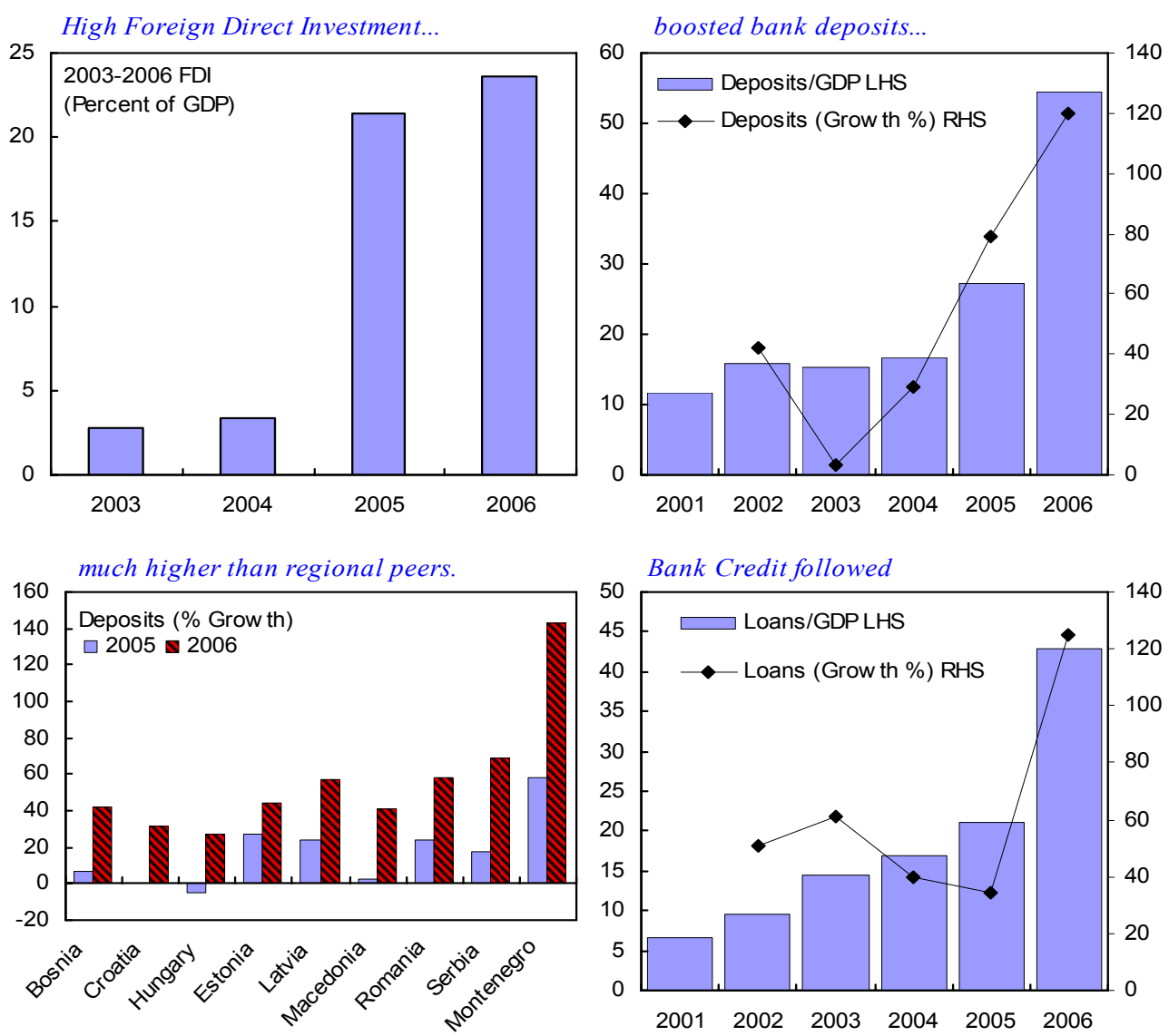

with a declining share of corporate loans...

owing to very rapid increases in household credit.
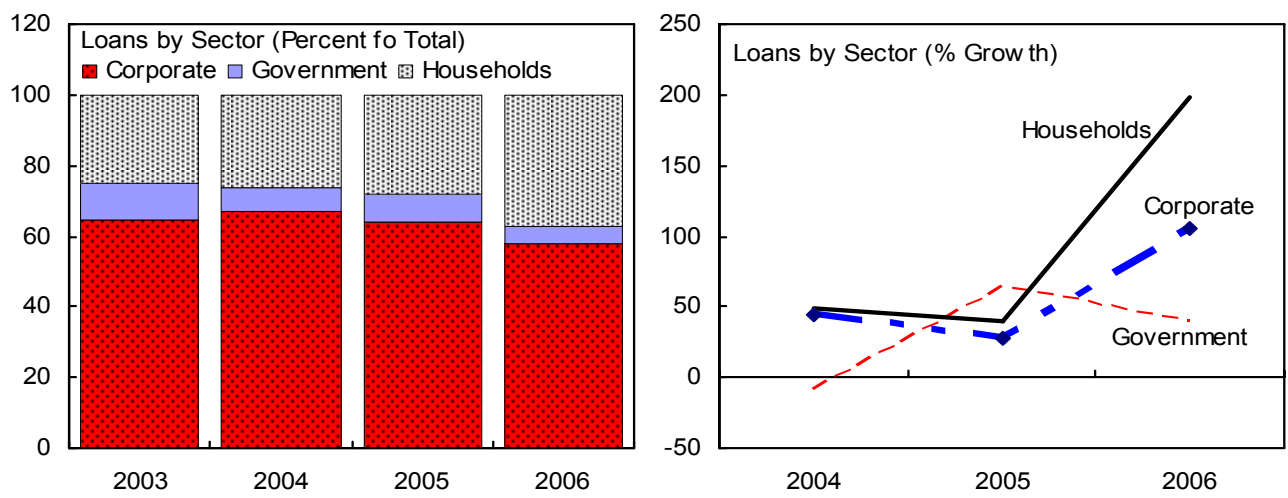

Source: Central Bank of Montenegro, IMF Staff estimates 
Table 1. Montenegro: Selected Economic Indicators, 2002-2007

\begin{tabular}{|c|c|c|c|c|c|c|}
\hline & 2002 & 2003 & 2004 & 2005 & 2006 & 2007 \\
\hline & & & & Prel. & Est. & Proj. \\
\hline & & \multicolumn{5}{|c|}{ (Annual percentage change) } \\
\hline Real GDP & 1.7 & 2.4 & 4.2 & 4.0 & 6.5 & 7.5 \\
\hline Retail prices (period average) & 19.7 & 7.5 & 3.1 & 3.4 & 2.1 & 3.5 \\
\hline Bank credit to private sector & $\ldots$ & $\ldots$ & 43.2 & 33.2 & 138.9 & 191.3 \\
\hline Enterprises & $\ldots$ & $\ldots$ & 40.6 & 30.2 & 112.2 & 198.4 \\
\hline Households & $\ldots$ & $\ldots$ & 49.4 & 39.7 & 193.0 & 180.7 \\
\hline \multirow[t]{2}{*}{ Bank deposits - private sector } & & $\ldots$ & 23.0 & 84.2 & 119.5 & 129.4 \\
\hline & \multicolumn{6}{|c|}{ (In percent of GDP; unless otherwise noted) } \\
\hline Revenue and grants & 37.2 & 41.8 & 37.8 & 37.4 & 44.9 & 50.7 \\
\hline Overall balance & -1.8 & -4.8 & -2.7 & -1.8 & 2.4 & 5.4 \\
\hline Primary balance & 0.0 & -3.7 & -1.1 & -0.6 & 3.6 & 6.6 \\
\hline Privatization receipts & 4.9 & 2.4 & 0.7 & 8.4 & 4.0 & 2.6 \\
\hline Central government deposits (end-of-period) & & 1.6 & 1.1 & 4.1 & 6.2 & 8.9 \\
\hline General government gross debt (end of period, stock) & 89.4 & 51.8 & 45.9 & 41.6 & 37.7 & 40.5 \\
\hline External debt & 68.7 & 33.2 & 29.6 & 28.9 & 26.1 & 22.3 \\
\hline Domestic debt & 20.7 & 18.7 & 16.4 & 12.7 & 11.7 & 18.1 \\
\hline Current account balance, excl. grants & $\ldots$ & -11.1 & -10.1 & -8.9 & -30.7 & -37.0 \\
\hline Foreign direct investments & & 2.8 & 3.4 & 21.4 & 23.6 & 24.4 \\
\hline $\begin{array}{l}\text { REER (wage-based; annual average change, in percen } \\
\text { ( - indicates depreciation) }\end{array}$ & & 4.4 & 6.6 & 7.9 & 7.4 & 3.6 \\
\hline Memorandum items: & & & & & & \\
\hline Population (millions) & 0.6 & 0.6 & 0.6 & 0.6 & 0.6 & 0.6 \\
\hline Nominal GDP (millions of euro) & 1,302 & 1,392 & 1,651 & 1,785 & 1,979 & 2,204 \\
\hline
\end{tabular}

Sources: Montenegro authorities, and staff estimates. 


\section{Key Financial Sector Risks ANd Vulnerabilities}

6. Main vulnerabilities are associated with the extremely rapid growth of the banking system - stress tests confirmed growing credit and liquidity risk. These vulnerabilities are exacerbated by stock market buoyancy, a weak disclosure regime, and the absence of the traditional lender-of-last resort function given unilateral euroization.

7. The banking sector has grown at a very rapid pace, particularly since 2006. Growth in assets was supported by an increase in deposits related to high capital inflows, and a greater formalization of the economy. There is a large and growing foreign presence in the banking sector: the largest bank was purchased in 2006 by Hungarian banking group OTP, and a foreign bank that commenced operations in 2006 already ranks fourth in terms of assets. However, not all foreign bank owners are internationally-rated financial institutions that can provide risk management expertise, as well as capital and liquidity support. There are also recent indicators that foreign banks are stepping up foreign borrowing now that a slowdown in deposit growth is observed. Some domestic banks have also been pursuing aggressive expansion strategies.

8. Financial soundness indicators, while not yet alarming, are rapidly deteriorating (see Table 3). Capitalization remains at a high level - the overall capital adequacy ratio for the banking system at end-June 2007 stood at 18.7 percent, but well below the over 30 percent rate at end-2004 - reflecting bank efforts to establish a more efficient balance sheet structure. ${ }^{3}$ However, liquidity indicators are becoming much tighter, with liquid assets falling to 25 percent of total assets at end-June 2007, and the loan-to-deposit ratio increasing to 95 percent - up from 88 percent one year earlier. Recently, earnings have increased on the back of growing interest margins - in sharp contrast to what was observed at the time of the FSAP missions, when strong competition for market share depressed profits and kept net interest margins under pressure. Although falling overhead costs have contributed to the rebound in profits, growth in bank employees has lagged well behind the credit expansion.

9. Appendix II provides greater detail on financial sector structure, including on the nonbank financial sector. The latter has experienced solid growth over the last few years, although well below that of the banking sector. Assets of the nonbank financial sector at end-2006 stood at about 16 percent of total financial sector assets. Leasing activity has taken off after the introduction of the Law on Leasing in 2005. Two stock exchanges compete for trading, mostly in a number of domestic investment funds.

\footnotetext{
${ }^{3}$ Excluding the effect of the reduction in risk weights on residential mortgages (from 100 to 50 percent) introduced in October 2006, capital adequacy would have fallen even further.
} 
Table 2. Montenegro: Structure of the Financial System, 2002-2006

\begin{tabular}{|c|c|c|c|c|c|}
\hline & 2002 & 2003 & 2004 & 2005 & 2006 \\
\hline \multicolumn{6}{|l|}{ Number } \\
\hline Banks & 10 & 10 & 10 & 10 & 10 \\
\hline Domestic majority owned & na & 7 & 7 & 3 & 1 \\
\hline State owned & na & 2 & 2 & 2 & 0 \\
\hline Private owned & na & 5 & 5 & 1 & 1 \\
\hline Foreign majority owned & na & 3 & 3 & 7 & 8 \\
\hline Insurance Companies & 4 & 5 & 6 & 6 & 6 \\
\hline Leasing Companies & 0 & 0 & 0 & 0 & 5 \\
\hline Micro credit enterprises & 2 & 2 & 2 & 2 & 4 \\
\hline Investment Funds & 6 & 6 & 6 & 6 & 6 \\
\hline Management Companies for Investment Funds & 6 & 6 & 6 & 6 & 7 \\
\hline Brokers & 5 & 5 & 6 & 9 & 15 \\
\hline of which with dealer licence & 0 & 1 & 1 & 1 & 3 \\
\hline \multicolumn{6}{|l|}{ NEX Montenegro Stock Exchange } \\
\hline $\mathrm{A} / \mathrm{B}$ listed companies & 0 & 1 & 1 & 3 & 3 \\
\hline Free market companies & 311 & 374 & 426 & 373 & 3101 \\
\hline \multicolumn{6}{|l|}{ Montenegro Stock Exchange } \\
\hline $\mathrm{A} / \mathrm{B}$ listed companies & 0 & 11 & 10 & 19 & 23 \\
\hline Free market companies & 346 & 368 & 375 & 368 & 3681 \\
\hline \multicolumn{6}{|l|}{ Financial system assets (in million of euro) } \\
\hline Banks & 340.5 & 349.8 & 444.4 & 695.8 & 1431.4 \\
\hline $\mathrm{o} / \mathrm{w} 3$ largest banks & na & 207 & 264.8 & 462.3 & 912.5 \\
\hline $\mathrm{o} / \mathrm{w}$ foreign majority owned & na & 82.1 & 137.8 & 610.2 & 1329.2 \\
\hline $\mathrm{o} / \mathrm{w}$ domestic majority owned & na & 267.7 & 306.6 & 85.6 & 102.2 \\
\hline state owned & na & 67.1 & 72.8 & 35.5 & 0 \\
\hline private owned & na & 200.6 & 233.8 & 50.1 & 102.2 \\
\hline Insurance Companies & 17 & 23 & 25 & 31 & 312 \\
\hline Leasing Companies & 0 & 0 & 0 & 0 & 423 \\
\hline Micro credit enterprises & na & 11 & 14 & 19 & 33.8 \\
\hline Investment Funds & 13.8 & 76.2 & 84.4 & 151.3 & 209.64 \\
\hline Management Companies for Investment Funds & 1.8 & 1.7 & 1.8 & 1.5 & 1.84 \\
\hline Brokers & 0.3 & 0.3 & 0.3 & 0.6 & 0.94 \\
\hline of which with dealer licence & 0 & 0.1 & 0.1 & 0.1 & 0.64 \\
\hline \multicolumn{6}{|l|}{ Assets as percent of GDP } \\
\hline Banks & 26.2 & 24.4 & 28.9 & 42.3 & 72.3 \\
\hline Non-bank institutions & na & 7.8 & 8.2 & 12.4 & 16.2 \\
\hline
\end{tabular}

Source: Central Bank of Montenegro

1/ End-September 2006.

2/ End-December 2005.

3/ End-June 2006.

4/ End-July 2006. 
Table 3. Montenegro: Financial Soundness Indicators of the Banking Sector, 2004-June 2007

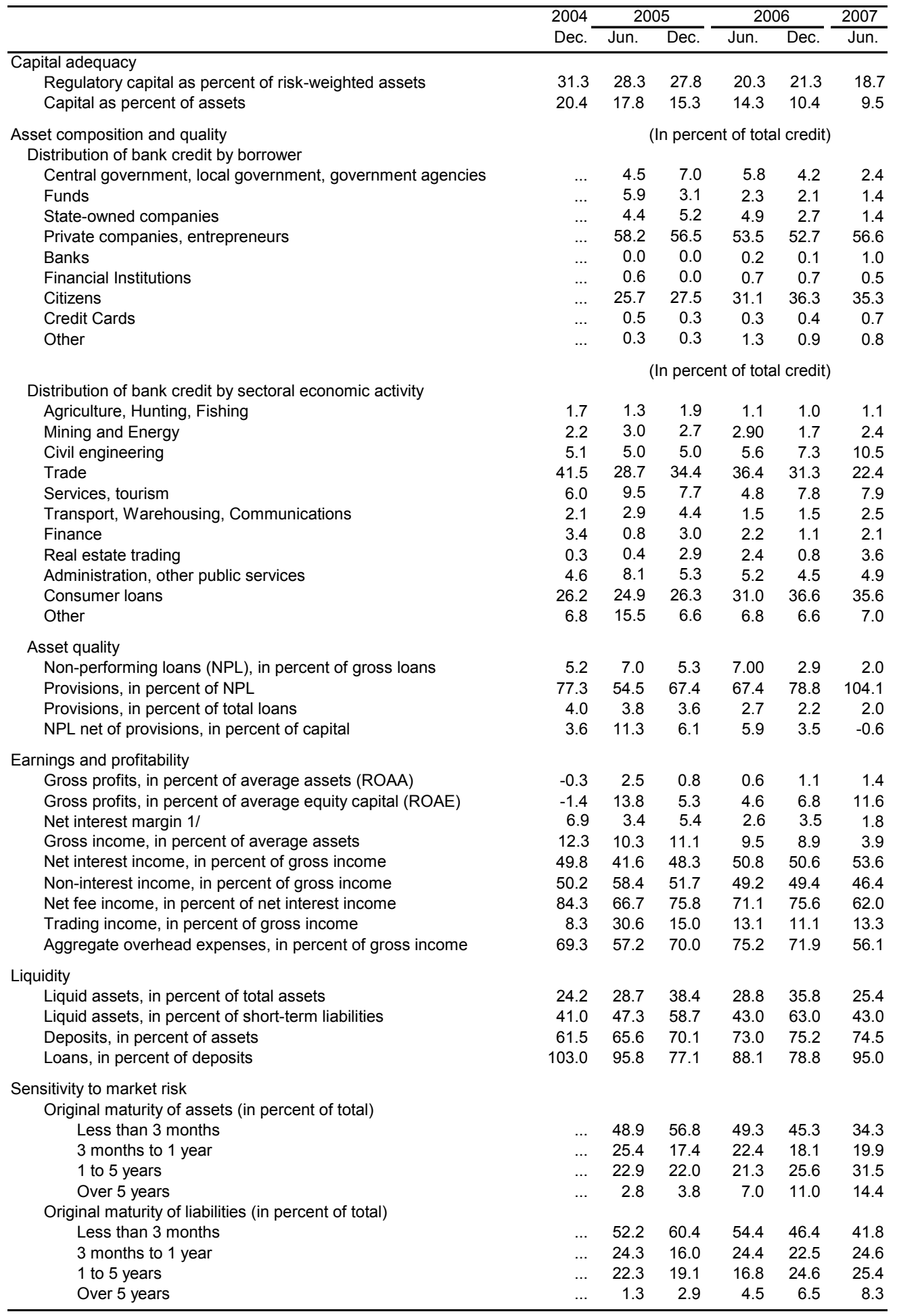

Source: Central Bank of Montenegro

$1 /$ Net interest income in percent of interest bearing assets 


\section{A. Rapid Credit Growth}

10. The current credit boom is taking its toll on banks' financial indicators. There are signs that banks hold insufficient provisions against credit risk: loan-loss provisions are low at 2 percent of total loans at end-June 2007. During examinations, the CBM found asset classification in most banks to be ridden with errors and too lax-NPLs were at a mere 2 percent at end-June 2007. ${ }^{4}$ Capital adequacy has come down in all but one bank during the twelve month-period ending in June 2007, but remain well above regulatory minima.

11. Banks' risk management practices leave room for improvement. The BCP assessment found significant weaknesses in banks' internal controls, as well as untested and under-resourced risk management processes; also trained credit officers are in short supply to cope with rapid credit growth. On average, the accuracy of bank clients' financial statements used in credit analysis is questionable - although a notable improvement was noted following the introduction of the VAT. In this context, rapid credit growth raises concerns that credit risk is not measured appropriately, nor managed adequately. ${ }^{5}$

12. Improving asset quality will depend on the adoption of a multi-pronged strategy that relies on banks, the supervisor, disclosure, and strengthening of institutions:

- $\quad$ Proper risk management is the responsibility of banks. Banks' business is to take on and manage risk, and their internal policies, procedures, and governance should be in line with modern risk management practices.

- Supervisors should validate and monitor the appropriateness of banks' systems and practices, and ensure that banks adopt corrective action if shortcomings are found. To this end, the supervisor should conduct additional reviews across banks of practices in critical areas such as risk management. These may highlight relative weaknesses, distill best practices, and result in issuing guidance notes. This should be supplemented by a periodic review of the prudential framework to determine whether the CBM can respond flexibly and resolutely to observed differences in risk management quality. Elements of this review include bank-specific capital adequacy levels, provisioning requirements, risk weights on certain assets, and other measures. The review may point to a need to strengthen the prudential framework.

- In the medium-term, strengthening the infrastructure for financial servicesincluding broadening access to the credit registry - should help manage credit risk. By making the credit registry accessible to banks and other credit providers, as

\footnotetext{
4 In periods of extremely high credit growth, nonperforming loans react with a lag of uncertain duration. The NPL average for 2005-2006 average was close to 6 percent.

${ }^{5}$ The authorities are also encouraged to collect and compile date on external private sector indebtedness and real estate prices, important indicators in a country with a credit boom and a rapidly changing financial system.
} 
is currently programmed for early 2008 , the paucity of reliable information, including as a result of poor accounting and auditing practices, can be partly overcome. ${ }^{6}$ Enhanced disclosure of financial information by bank clients is critical in imposing stronger discipline on market participants. In the banking system, pillar three of Basel II explicitly requires better disclosure to properly assess the risk profile of banks. The same applies to bank borrowers.

13. Recent CBM measures have not yet shown any effect on credit growth, increasing the urgency for adopting the Law on Banking that would enable further strengthening risk-based supervision. The measures, which will mostly take effect on January 1, 2008, include: (i) increased reserve requirements; (ii) ceilings on credit growth ranging from 30 to 60 percent per annum of the loan portfolio depending on the size of the bank; (iii) higher provisions on new loans; and (iv) increases in capital adequacy ratios for banks with rapid credit growth.

14. Regional experience suggests that measures aimed at stemming credit growth often are ineffective while having unintended consequences. Direct controls such as credit ceilings may lead to regulatory arbitrage, where similar products are offered through nonbank channels (e.g., leasing companies), with little macroeconomic, and only some prudential, relief. Other, less distortionary measures of a prudential nature could be considered, including reversing the reduction in risk weight of residential mortgages. ${ }^{7}$

\section{B. Vulnerabilities Associated with Unilateral Euroization}

\section{Unilateral euroization limits the scope for addressing vulnerabilities. In} particular, the scope for the CBM to act as a lender-of-last-resort or to tighten monetary conditions is strictly limited. However, even within these constraints, there are opportunities to promote financial stability.

\section{Strengthening liquidity in banks}

16. Given the limited access to a lender-of-last-resort facility, bank liquidity management should be more conservative than otherwise. Care is needed to avoid assuming that foreign ownership mitigates this need. Foreign-owned subsidiaries remain vulnerable to sudden loss of support from headquarters due to changing financial and economic conditions in home and host countries, as well as to potential cross-country contagion via, inter alia, (i) bank runs abroad; (ii) wholesale funding problems; or

\footnotetext{
${ }^{6}$ Information in the credit register should cover all bank credits. Other payments useful for assessing payment discipline should also be included, especially if the collection of such information does not impose much additional cost (e.g., utility payments).

${ }^{7}$ The risk weight on residential mortgages was reduced in October 2006 to bring it in line with the Basel Capital Accord.
} 
(iii) interbank market liquidity problems. This vulnerability may be more acute for banks that are domestically owned or owned by unrated foreign banks or investors.

\section{Supervisors, therefore, should consider further tightening the liquid asset} requirements. Current regulation imposes stricter liquidity requirements as asset quality, measured by the level of NPLs, deteriorates. However, in periods of rapid growth, these indicators lag, at a time when greater prudence is needed. This suggests, as a first step, to suspend the lower liquidity requirement until credit growth has returned to a more modest pace. Another option would be to establish liquidity requirements that take into account the strength of banks' available liquidity support, including contingent credit lines.

\section{Moving public deposits to CBM}

18. Public deposits in Montenegro are sizeable, concentrated in few banks, facilitate rapid credit growth, and pose governance problems. Deposits and borrowings by public entities have doubled from end-2003 to mid-2006, to about 18 percent of total deposits and 15 percent of total loans. Deposits exceed borrowings throughout the period by a substantial margin. About half of the deposits arise from the Development Fund, though lending is more evenly distributed between the MoF, the Development Fund, municipalities and state enterprises. Deposits and borrowings are concentrated: one bank has 65 percent of public sector deposits, accounting for 23 percent of its deposit base. This means that a sudden withdrawal of deposits could be destabilizing, although most are time deposits that serve to guarantee loans. Since, as noted above, public deposits also contribute to funding credit growth, shifting these deposits to the CBM would also ease inflation pressures. These deposits also pose governance problems: (i) the public sector does not face the same riskreturn trade-offs as private agents - even if offered high rates of return on deposits, the riskadjusted return may be low; and (ii) low deposit rates or non-transparent conditions could create opportunities for corruption.

\section{Central government deposits above levels needed for transactions should be} transferred to the CBM in a timeframe that allows for the smooth adjustment of bank funding. These deposits include those of the Development and other Funds. The timeframe should be set to take into account the maturity of associated loans, and mitigate potential risks on the banks' funding side. The deposits should be remunerated appropriately by the CBM. State-enterprise deposit placements and other transaction accounts should be transparently competed amongst qualified banks.

\section{Stress Testing}

20. This section describes the results from credit and liquidity risk stress tests to evaluate the sensitivity of the banking system to a number of possible shocks. The results of the credit risk stress tests deserve special attention in light of the rapidly growing credit stock. Initial stress tests were performed by the mission team in mid-2006. The results have 
been updated based on calculations by the authorities on end-June 2007 information. ${ }^{8}$ Two groups are distinguished: large versus small banks (as measured by asset size), with each group containing five banks. Recently, banks have started to conduct internal stress tests.

\section{Credit risk stress tests}

21. The consequences of the high lending growth, the existing sectoral and large borrower concentration were examined through a series of credit risk stress tests. A first test simulates the effect on capital adequacy of migrations of the credit portfolio to lower asset classifications: 10 percent of assets in Category A migrate to Category B, with further migrations of 15,20 , and 40 percent to Categories $\mathrm{C}-\mathrm{E}$, respectively. In the simulations, provisions are increased in line with existing regulations. In the second test, the results of the first test are worsened by an additional increase in NPLs of 50 percent, and provisions are increased by 30 percent, to simulate a further worsening of the credit portfolio, as might occur under a hard landing scenario where credit risk might increase sharply with a slowdown in activity. A third credit risk test simulates the effect of the default of a large borrower, defined as the median value of the largest 20 borrowers.

22. The impact of the credit risk stress tests for one large bank is quite severe-under the first two stress tests, its CAR falls below the required minimum 8 percent (Table 4). Other banks maintain capital above 10 percent under the first test, but two additional large banks fall below that threshold under the more severe test. In the stress tests conducted earlier on the basis of June 2006 data, a different large bank-since recapitalized - fell below the required minimum CAR. The effect of default of a single (median-sized) large borrower, which provides an indication of concentration of the credit portfolio, does not put any bank below regulatory norms. This is in contrast to the stress test performed on June 2006 data, when one large bank's CAR fell below the required 8 percent minimum, indicating a reduction in credit portfolio concentration during the last year.

\section{Liquidity risk stress test}

23. The liquidity of the banking system has deteriorated significantly since the FSAP mission, but remains above prudential norms. Coverage of customer deposits by cash, bank deposits and other liquid assets decreased from nearly 40 percent in end-June 2006 to around 34 percent at end-June 2007. This level is achieved thanks to high compliance with reserve requirements - recently increased - and the regulation on liquid assets, although bank-by-bank variations are large.

24. Sensitivity to liquidity risk is tested through two means: (i) a generalized loss in depositor confidence; and (ii) deposits withdrawals limited to larger depositors, including

\footnotetext{
${ }^{8}$ Market risk stress tests were also performed (interest rate and foreign exchange rates), but in light of the low exposure to these factors, the impact of market risk shocks was modest.
} 
public sector deposits. The stress tests measure whether banks can meet these withdrawals using freely available liquidity (cash and free reserves).

25. The results of the liquidity stress tests indicate that some banks experience tight liquidity conditions, and have a relatively high degree of deposit concentration. This is partly owing to the starting liquidity position at the date of the stress test, where one bank does not have free liquidity. Two large banks cannot meet the first three hypothetical withdrawal shocks from free liquidity, and must tap into their required reserves, which is permitted. If all public sector deposits were withdrawn, one bank would run out of free liquidity. Other banks also have significant public sector deposit concentration: in four banks, public sector deposits account for more than 13 percent of total deposits; in two banks the share is greater than 20 percent.

Table 4. Montenegro: Summary Results of Stress Tests

\begin{tabular}{|c|c|c|c|c|c|}
\hline & \multirow[t]{2}{*}{$\begin{array}{l}\text { Total } \\
\text { System }\end{array}$} & \multicolumn{2}{|c|}{ Large Banks } & \multicolumn{2}{|c|}{ Small Banks } \\
\hline & & Low & High & Low & High \\
\hline Capital adequacy ratio & 18.7 & 13.7 & 16.8 & 17.5 & 196.9 \\
\hline \multicolumn{6}{|l|}{ Credit stress test (post-shock CAR) } \\
\hline 1. Migration to lower asset categories & 14.3 & 5.7 & 16.1 & 11.9 & 199.0 \\
\hline 2. Increase in NPLs & 13.0 & 3.5 & 15.7 & 10.1 & 201.8 \\
\hline 3. Large exposures & 17.4 & 11.8 & 16.5 & 16.7 & 198.3 \\
\hline $\begin{array}{l}\text { Free liquidity (cash and free reserves, as a } \\
\text { percentage of total deposits) }\end{array}$ & 18.0 & -5.7 & 36.6 & 22.2 & 445.5 \\
\hline \multicolumn{6}{|l|}{$\begin{array}{l}\text { Liquidity stress test (free liquidity } \\
\text { available after shock, as a percent of } \\
\text { total deposits) }\end{array}$} \\
\hline 1. 15 percent of deposits withdrawn & 3.0 & -20.7 & 21.6 & 7.2 & 430.5 \\
\hline 2. loss of largest depositor & 10.5 & -14.1 & 34.1 & 15.7 & 371.2 \\
\hline 3. loss of 50 percent of top ten depositors & 5.4 & -24.6 & 31.1 & 8.2 & 399.4 \\
\hline 4. loss of public sector deposits & 5.5 & -31.5 & 35.8 & 0.8 & 440.9 \\
\hline
\end{tabular}

\section{Stock Market Volatility}

26. A significant correction in stock market prices is underway. The market had been extremely buoyant in recent years, and the NEX and MOSTE indices rose by 338 percent and 373 percent during the 12 months to end-April 2007. Since then, the market has dropped, with prices down about 40 percent from the April peak. The factors underlying the earlier boom are difficult to gauge, but may have reflected low initial valuations. Turnover has been 
relatively low at less than EUR 2 million per day (both exchanges combined, 2006), whereas capitalization has reached a high level compared with other countries (Figure 2).

\section{There are number of governance and stability concerns with regard to}

Montenegro's stock markets. Disclosure requirements are weak-reporting is not timely, and filing violations not enforced - and trading does not seem to be based on new information. The Securities and Exchange Commission has yet to investigate suspect trading, and has no proven enforcement record. Although there are currently only weak links with the banking system (some banks hold stock, and there is a small amount of bank lending against share collateral-so-called "Lombard loans"), high market returns have tempted bank customers to migrate, and take on much more risk. Although precise figures are not available, the fast-growing payroll consumer lending (typically up to EUR 5,000 per loan) can be used to purchase shares. Indirect effects on credit risk through declining net worth of households are expected to be small, since debt service is collaterized by wage payments; however, such effects would depress growth.

Figure 2. Montenegro: Stock Market Capitalization (In percent of GDP, 2003-06)

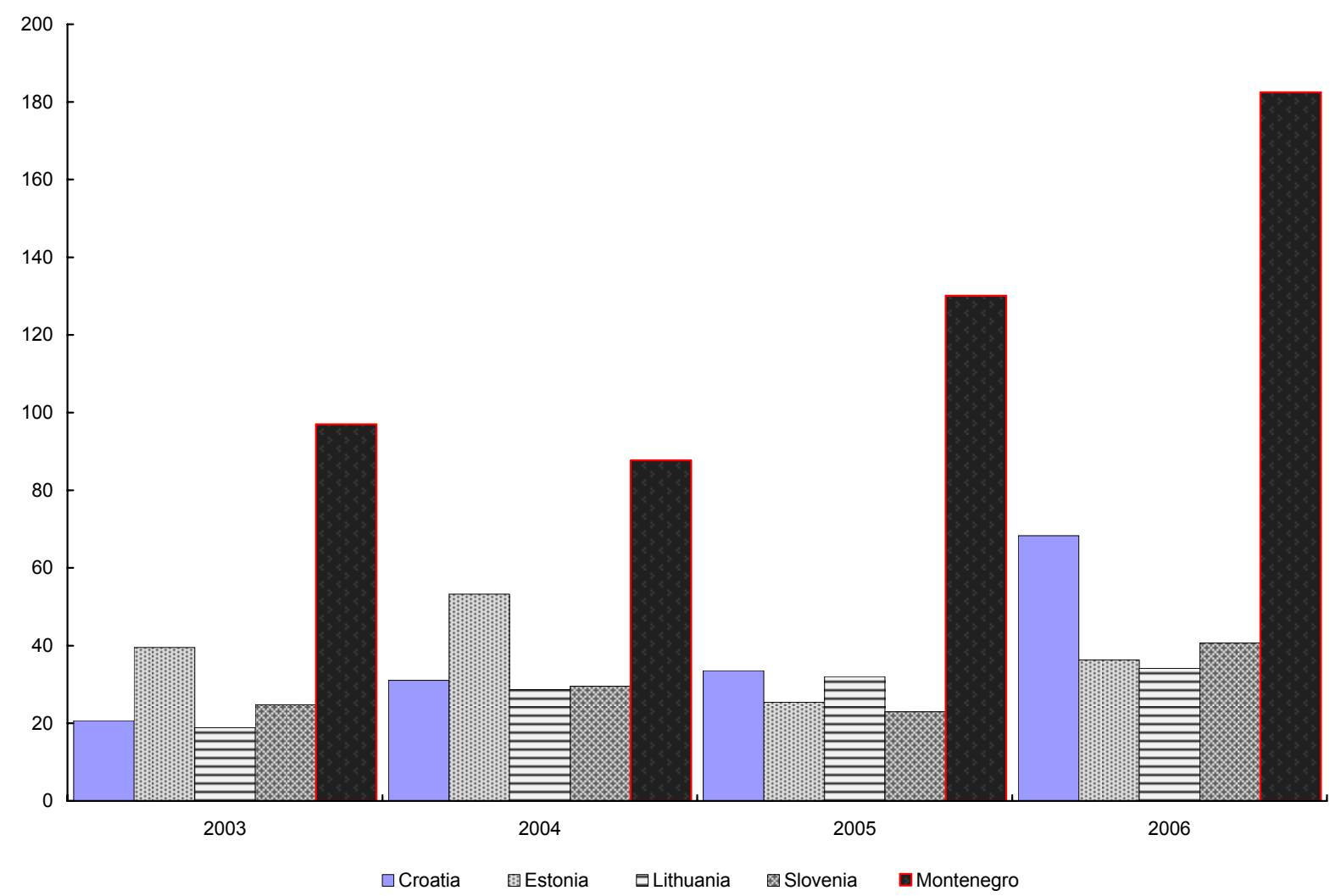




\section{STRUCTURAL ISSUES}

\section{A. Prudential Supervision}

28. An assessment of the Basel Core Principles for Effective Banking Supervision undertaken in the context of the FSAP found overall compliance satisfactory. Areas in need of improvement included: (i) internal controls of banks; (ii) insufficient legal protection of CBM supervisors; and (iii) relatively weak enforcement powers.

29. Banking supervision in Montenegro has been effective. Individual banks are overseen through a process of periodic offsite analysis and a system of onsite inspections. The CBM has operational independence in performing its supervisory functions, and there is no evidence of governmental or industry interference in supervisory decision-making. The CBM also enjoys financial independence from government. It directly levies fees for its bank regulatory and examination activities. Senior staff and inspectors have made progress in effectively incorporating best international practices, especially by promoting stronger risk management in key areas including the operations and internal controls of the banks. They are knowledgeable about the risks facing both the banking sector as a whole and individual banks. The CBM employs the corrective measures available to it in the laws. Its examiners have also been proactive in ensuring that banks comply with the legal requirements for antimoney laundering processes and procedures.

30. It is important to swiftly adopt the draft Law on Banking (LOB) to strengthen the legal framework for banking supervision, in a rapidly changing environment of extremely high credit growth. Past MCM/LEG technical assistance suggested to strengthen the draft amendments along various directions, including:

- $\quad$ Strengthening the corrective action and problem bank resolution procedures;

- $\quad$ Providing that the execution of a CBM resolution should not be suspended in cases where the resolution seeks to address an imminent threat to depositor's interests;

- $\quad$ Strengthening the provisions dealing with the exchange of information with foreign supervisory authorities;

- $\quad$ Permitting the conduct of on-site inspections by foreign financial sector supervisors in Montenegro;

- $\quad$ Expanding the fit and proper criteria to include senior management and the directors and managers of financial holding companies;

- $\quad$ Providing that banks must apply AML/CFT legislation and that compliance with such laws will form part of the bank examination procedures;

- $\quad$ Empowering the CBM to divest owners of their qualified participation where such has been acquired without prior CBM approval; and 
- $\quad$ Strengthening the independence requirements for non-executive directors.

31. Once the draft Law on Banking is adopted and implementing regulations issued, important gaps are likely to remain in the legal and regulatory framework. Although formally the legal regime complies closely with international standards, the supervisor lacks enforcement powers common in other jurisdictions that are necessary to carry out its mandate. In particular, the following weaknesses need to be addressed:

- $\quad$ Providing protection for the CBM, its officers, staff and agents against liability for damages caused by such persons in the good faith performance of their duties;

- $\quad$ Empowering the CBM to impose appropriate remedial measures in individual situations;

- $\quad$ Authorizing the CBM to impose monetary penalties directly on banks without having to first obtain court approval; and

- Inadequate access to judicial review: the administrative court decision cannot be appealed.

32. Since 2005, the disparity between the available resources and growing needs in exercising supervision became more pronounced. As a result, a new organizational structure of the Bank Supervision Department was developed and recently adopted. The new structure is grounded on the objective of strengthening supervisory capacities to meet the existing and anticipated needs, in particular to focus increasingly on risk-based supervision and preparing for consolidated supervision, as the banking system increases its product range, including insurance products and securities services.

\section{B. Rethinking the Supervisory Architecture}

33. As a small country, Montenegro has an even greater need to consider steps to reduce the fixed-costs of its supervisory system. Although there are no uniformly agreed optimal supervisory arrangements, the case for unified supervision grows stronger as the financial sector becomes more integrated.

34. Insurance supervision is currently not well organized and staffed. In June 2006, only three staff in the MoF were dedicated to this task, lacking adequate resources to discharge this function. The new draft Law on Insurance contemplates the creation of a separate insurance regulator, but international experience indicates that the costs involved would be substantial. Moreover, considering that the insurance industry in Montenegro is very much at an embryonic stage and could grow quickly, it may be preferable to empower the CBM to serve as the insurance regulator, provided potential legal obstacles can be overcome.

35. Another supervisory challenge is posed by the emergence of conglomerates. The first financial/mixed conglomerate is currently still small and there seems to be no evidence 
of irregular relationships between the bank and its connected parties. Nevertheless, it is on a high growth path, and other conglomerates are likely to be formed. The CBM has already adopted the regulatory framework consistent with the EU Banking Directive, and is now turning its attention to implementation issues. Consolidated reports have been filed since mid-2006, and the 2007 onsite examinations have looked at consolidation issues.

\section{Banks are likely to act as securities brokers/dealers before long, raising similar} supervisory organizational issues. At a minimum, this will require closer cooperation between the Securities and Exchange Commission (SEC) and the CBM in this area. Moreover, as seen in other countries, consolidated supervision would be facilitated by the establishment of a single supervisory agency in the future. It may be desirable to commission a study of this issue. Also, the EU Capital Adequacy Directive principles for broker/dealer activities should be based on same basic (but simplified) methodology as for banks. An increasing need for more international cooperation must also be foreseen.

\section{Efficient Liquidity Management}

37. Over the medium-term, Montenegro should aim to gradually converge the conditions prevailing in its financial system to that in the Eurozone. Montenegro's banks would benefit from integrating to the extent possible with the deep and liquid euro money market to achieve economies of scale in liquidity management. Although there are no formal restrictions on access to euro area money markets, high rating and transaction costs, as well as concerns about legal security and other potential reputational issues, may pose obstacles for some banks. ${ }^{9}$

38. To achieve a more stable balance sheet structure over time, banks should be encouraged to limit short-term liabilities, and move longer term assets off their books. One option would be to include incentives in the liquidity regulation that would favor deposit contracts not subject to early withdrawal optionality. Similarly, it would be important to explore ways to securitize longer term assets, such as mortgages, for sale to agents with longer investment horizons, such as pension funds and insurance companies, while being alert to the risks of the originate-and-sell business model of bank lending.

39. The recently adopted liquidity ratio requirement should be the principal framework for banks' prudential liquidity management. This would allow for a thorough simplification of the reserve requirement regime over time. This process can be guided by the existing Eurosystem framework, with only one rate for liabilities up to two years. As the reserve requirement is changed, the liquidity ratio (currently 10-15 percent daily and 15-20 percent ten-day liquidity ratio, depending on asset quality indicators) and the remuneration on required reserves would need to be adjusted to ensure a neutral impact on

\footnotetext{
${ }^{9}$ Unrated banks can place deposits without constraint but not borrow at low cost, even with collateral (e.g., bank deposits) in place.
} 
banks. As noted above, urgent consideration should be given to tightening the liquidity regulation during periods of rapid credit growth.

40. The option of holding $\mathbf{1 0}$ percent of required reserves in domestic treasury bills should be removed. It creates a captive market for these bills, so that the yield does not reflect the risk of such instruments. ${ }^{10}$ In line with international practice and as financial markets develop; the CBM could develop collateralized intraday credit to allow interest-free use of intraday funds. Finally, to allow more flexibility in liquidity management, the 50 percent limit on the use of reserve requirements should be removed and averaging allowed over the entire maintenance period.

41. The interest rates on the standing facilities of the CBM should be referenced to the relevant ECB rates. CBM currently grants credit to banks through intraday and overnight facilities up to 80 percent of the nominal value of the collateral, which has to consist of securities issued by the Republic of Montenegro or an EU member state. For both facilities, CBM charges interest at the rate determined in the latest treasury bill auction. As the treasury bill rate is very volatile and the primary market virtually inactive, the rate should instead be set as the ECB overnight interest rate plus an appropriate margin.

\section{Financial System Infrastructure}

\section{Payment and settlement systems}

42. A Law on Payments and Settlement is needed, which could be based on the draft Law on the Transfer of Funds, Electronic Payment Instruments and Payment Systems. LEG technical assistance has advised to break this draft law up into several legal acts, including a "Law on the National Payment System. Substantive revisions will be needed in order to bring it in line with international best practice, including: (i) irrevocability and timing of settlement finality for all types of payment instruments and systems operating in Montenegro; (ii) legal recognition and protection of netting arrangements (in the context of insolvency); (iii) the use of collateral pledges and clear provisions on the legal admissibility in a court of payment instructions, messages and transfers through electronic systems; and (iv) e-based payment instruments.

43. While the CBM actively oversees compliance with payment systems regulations, it does not monitor settlement systems involving credit and debit cards. The settlement and clearing of such electronic payment instruments are arranged by individual banks, instead of a national settlement and clearing system; neither is there a national standard that would allow for efficiency-enhancing interoperability between various systems, including ATMs and POS devices. The CBM has no information about the details of these systems and does not exercise any oversight. The CBM should take a more active role in coordinating efforts to achieve greater efficiency. As a minimum, the CBM should establish the technical

\footnotetext{
${ }^{10}$ Lowering the reserve requirement ratio or increasing its remuneration could compensate banks for this.
} 
parameters ensuring effective interfaces with the low value payment system and a sharing of the e-payments related infrastructure.

44. Improving access to non-cash payment services and reducing the costs and risks related to such transactions is particularly important in Montenegro. Cash is the least efficient way to make payments, among other reasons since use of euros incurs significant opportunity and logistic costs. Continued cash use is related to inconvenient access to, and higher costs and risks associated with, other payment instruments.

\section{Accounting and auditing}

45. Auditing and accounting practices are in need of improvement. Although Montenegro requires larger companies to abide by International Financial Reporting Standards (IFRS), the practice varies greatly. Compliance with IFRS by banks generally appears to be good and equal to peers in other EU Member States. However, financial reporting by large listed nonbank companies is mediocre due to incomplete disclosures, questionable asset valuations and poor accounting for taxes, while reporting by small and medium-sized enterprises remains poor. There is limited enforcement of financial reporting regulations, and corporate management does not have incentives to change accounting treatments to be in line with IFSR. In the case of joint stock companies, financial statements must be audited in accordance with International Standards of Auditing. However, the quality of audits is very uneven and external quality control over the country's 32 licensed auditors does not exist.

\section{E. Nonbank Financial Institutions}

46. The current regulatory framework for the insurance sector is dated, falls short on regulatory reporting and limits the rights of the regulator to conduct on-site supervision. The new law would substantially expand the rights of the regulator and encourage further competition. However, several issues in the present draft law should be reconsidered, including: (i) increasing minimum capital requirements; (ii) strengthening licensing requirements; (iii) developing a chapter for insurance contracts law to overcome inadequacies in general contractual law; and (iv) removing discriminatory limits on the types of business that can be written by licensed branches of foreign insurers.

\section{Access to financing}

47. Large firms cannot rely entirely on domestic banks for their financing needs, given the small financial system. Hence, they resort to borrowing directly from abroad, either through intermediation by local subsidiaries of foreign banks, or directly from other lenders. Other alternatives include loan syndication and capital market access.

\section{F. Capital Markets and Pensions}

48. Montenegro has made remarkable progress in establishing a capital market in the last five years. The market is regulated and supervised by the SEC which also oversees 
the two exchanges, the centralized share registry (the Central Depository Agency, CDA), the licensing and operation of broker/dealers, the investment fund industry and the issue of new listings. It operates with a relatively small staff and appears to be reasonably cost-efficient. ${ }^{11}$

49. The weakest element in the SEC supervisory structure is the absence of a robust enforcement mechanism. The SEC has no power to levy fines or impose other monetary penalties. For serious abuses, such as cases of insider trading or other market abuses, it can resort to criminal law but there have been no such cases to date possibly because of evidential difficulties and inefficiencies in the court system. It is important to create precedent in judicial handling of such criminal cases. A key element in any regulatory system is the ability of the regulator to penalize violations - the authorities should be encouraged to amend the law to allow for the imposition of monetary penalties.

50. Both stock exchanges should move to one common trading platform, providing a useful reorganization of the listing structure and additional operating efficiency. In addition to the listed market, the exchanges operate free markets, where traded companies are not subject to the same reporting requirements or other market controls as listed companies, giving rise to concerns of valuation and manipulation. At end-2006, there were six investment funds, whose shares are traded on the two exchanges.

51. The main weakness of the capital market sector is the lack of domestic institutional investors such as planned pension funds or life insurance companies. A competent and knowledgeable institutional investor base would also play a key role in improving corporate governance knowledge and practices and in encouraging much-needed improvements in the quality of financial statements and audits.

52. As the capital market matures and the pressure to conform to EU standards increases, major changes will be needed to the structure and operation of the sector. Most important in this regard will be the introduction of European passports for intermediaries and risk-based capital adequacy measures for brokers especially for dealers and abandoning the present all securities must be traded on the exchange principle.

\section{G. Legal Framework}

53. Montenegro has made significant progress over the last six years in developing a sound legal and policy framework for the financial sector. New laws dealing with banking, companies, bankruptcy, movable and immovable property security, competition, consumer protection, and the judicial sector as well as other non banking financial sector-

\footnotetext{
${ }^{11}$ It is recommended the authorities undertake a full assessment of the IOSCO principles of securities regulation beyond the self-assessment that already exists. The assessment should pay particular attention to (i) principles relating to the regulator; (ii) principles for the enforcement of securities regulation; (iii) principles for cooperation in regulation; (iv) principles for issuers, including on the full, timely and accurate disclosure of financial results and other information that is material to investors' decisions; and (v) principles for market intermediaries.
} 
related issues have been adopted in the last five years. These laws are well-drafted, comprehensive and generally in accordance with best international practice. In some key respects, particular legal issues remain to be addressed and there are some concerns regarding implementation and enforcement. The government is introducing amended financial sector legislation now that Parliament has adopted the new constitution.

54. The new Constitution provides that the CBM is an independent organization, and identifies the areas the $\mathrm{CBM}$ is accountable for, including monetary and financial stability and the functioning of the banking system. It should be assured that the draft amended Central Bank Law and the Law on Banks are revised to bring these acts as much as possible in line with international standards and best practices for central banking legislation. Apart from the needed improvements to the Law on Banks already mentioned in the context of strengthening banking supervision (paragraph 29), of particular concern in this regard are: (i) prioritization of CBM's objectives; (ii) the ability of the CBM to impose administrative sanctions to address prudential infractions without prior court approval, as the sole agency in this domain; (iii) limits on the judicial review of decisions of the CBM, especially those related to its supervisory role; and (iv) protection for the CBM, the members of its decisionmaking bodies and staff, and its agents against liability for actions taken and/or omissions made while discharging their duties in good faith.

55. The Law on Bank Bankruptcy and Liquidation is also undergoing technical review. Appeals under this law made clear that the $\mathrm{CBM}$ did not have the right to challenge the decision of the Administrative Court. A further concern is the view taken by some jurists that the Administrative Court has the power to review and reverse decisions of the CBM that it believes to be procedurally defective and/or simply wrong in substance. While judges must have the right to correct procedural irregularities they should not be permitted to substitute their judgment on the technical merits of an issue for that of the CBM. To allow otherwise is to create a situation where the courts become the ultimate regulator of the banking system rather than the CBM.

\section{H. Anti-Money Laundering and Combating the Financing of Terrorism}

56. The authorities have been addressing many of the shortcomings identified during an assessment of Montenegro's AML/CFT regime. The assessment, performed by the Committee of Experts on the Evaluation of Anti-Money Laundering Measures (MONEYVAL) that visited Serbia and Montenegro in 2003, was issued in January 2005, based on an earlier version of the assessment methodology. ${ }^{12}$ Key changes implemented since then are an amended AML/CFT law explicitly addressing issues related to the financing of terrorism, as well as the start of operations of the financial intelligence unit. MONEYVAL is planning to conduct a new AML/CFT assessment of Montenegro in September 2008. The assessment report will be presented to the MONEYVAL plenary for

${ }^{12}$ The AML/CFT ROSC for Serbia and Montenegro was issued to the Executive Board (IMF Country Report 06/96, January 17, 2006) 
adoption possibly within the first half of 2009, after which an AML/CFT ROSC will be prepared and circulated to the IMF Board for information. 


\title{
APPENDIX I: ObSERVANCE OF FINANCIAL SECTOR STANDARDS AND CODES—SUMmaRY ASSESSMENT
}

\author{
Basel Core Principles for Effective Banking Supervision
}

\section{General preconditions for effective banking supervision}

57. The CBM is the sole supervisory authority for banks operating in Montenegro. It operates within a supportive legal framework and is empowered to issue regulations, which allow for the effective implementation of relevant laws. The Law on Banks is being revised and proposed changes to it will enhance the capacity of the supervisory function to carry out its mandate.

58. Banking supervision in Montenegro is effective, providing the CBM with the means by which to monitor the banking sector as a whole. In addition, individual banks are overseen through a process of periodic off-site analysis and a robust system of on-site supervision. The CBM has operational independence in performing both its monetary policy and supervisory functions. There is no evidence of governmental or industry interference in supervisory decision-making. By law, most major supervisory decisions have to be taken by the CBM's governing body (its Council) which includes among its members the Deputy General Director with responsibility for banking supervision. The CBM also enjoys financial independence from government. It directly levies fees for its bank regulatory and examination activities, and is also free to employ its income from other activities in the supervision budget.

59. The senior staff of supervisors and inspectors is highly knowledgeable and has made great strides to effectively incorporate best international practices into the supervisory function especially by promoting stronger risk management in key areas including the operations and internal controls of Montenegrin Banks. They are knowledgeable about the risks facing both the banking sector as a whole and individual banks. The CBM employs the corrective measures available to it in the laws, while its examiners have also been proactive in ensuring that banks comply with the legal requirements for anti-money laundering processes and procedures.

60. In 2005, the disparity between the available resources and growing needs in exercising the supervisory role became more pronounced. Special attention is being devoted to redesigning the organizational structure of the Banking Supervision Department (BSD). The new organizational structure is grounded on the objective to strengthen supervisory capacities to meet the existing and anticipated needs in the near future.

\section{Institutional and macroprudential setting, market structure overview}

61. See Appendix II for an overview of the banking sector. 


\section{Main findings}

62. The main findings of the assessment of the implementation of the Basel Core Principles are grouped under the following main categories of core principles.

\section{a) Objectives, autonomy, powers, and resources (CP 1)}

63. The legal provisions governing the CBM's supervision of banks conform closely with all international standards. However, there is no specific legal protection for the CBM, its officers, employees and agents when they are performing supervision in good faith. Protection is needed for all these persons in the limited area of countering claims for compensation for financial losses, which are alleged to have been caused by supervisory measures taken in good faith in accordance with the law. The protection provided should not apply in respect of unauthorized actions, deliberate negligence or criminal offences acts committed by the CBM (or its representatives) during the course of performing supervision. In addition, the law does not explicitly provide for the disclosure of confidential information to other financial supervisors, although the CBM has already taken such action, on the basis of its by-laws, as part of its cooperation with other authorities. It is recommended that the new Law of Banks should address both of these areas.

64. At present the CBM enjoys adequate resources for performing supervision effectively. However, in view of the very rapid development of the banking sector, it will have to be alert to the need to attract and retain adequate human resources for its supervision.

\section{b) Licensing and structure (CPs 2-5)}

65. Supervision in these areas complies with international standards. It is recommended that the new Law of Banks should apply the same standards of personal integrity to senior managers of banks (heads of functions) as it does to members of their managing boards.

\section{c) Capital adequacy (CP 6)}

66. The CBM's current requirements for capital adequacy implement the Basel Capital Accord (Basel I) very effectively (the only reservation being an apparent lack of clarity regarding the definition of those general reserves which are eligible to be included in Tier 2 capital). The CBM is also keen to apply relevant elements of Basel II, and the LOB already allows the application of differing minimum capital (solvency) ratios to individual banks.

\section{d) Prudential regulations and requirements (CPs 7-15)}

67. Rules and regulations covering requirements of criteria, practices and procedures for extension of credit are adequately addressed by the Decisions issued by the CBM. The procedure for classifying the assets of a bank exposed to credit risk and the 
procedures for establishing special loss reserves for assets exposed to credit risk are mandated by Decisions issued by CBM. The current asset classification system consists of 5 risk groups - category A (Pass/Good loan) to Category E (Loss) with provision requirement ranging from 1 percent for the Pass category, to a range of 2 to 10 percent for the B Category (Special Mention credits), followed by a range of 20-30 percent for the C category (substandard category), and a range of 50-75 percent for the Doubtful category. Category E (loss) has a provision requirement of 100 percent. The ranges for the category B and C Loans are wide and should be decreased. The CBM's Decision considers Past due loans of 30 to 90 days as Special Mention credits; such credits should be classified as Substandard. The extremely fast growth of the banks' credit portfolios within the last two years, has led the CBM to develop a Credit Register that currently is only available to the bank supervisors, but by the end of 2006 will be open to all the banks.

\section{e) Methods of ongoing supervision (CPs 16-19)}

68. Through a combination of full scope and targeted on-site examinations, off-site surveillance and regular formal and informal meeting, senior management of Bank Supervision has a thorough understanding of the activities of the financial institutions it supervises. BSD senior management prepares an annual plan for its examinations which specifies the priority areas to be reviewed in each bank and the resources to be employed. It conducts full scope on-site examinations of banks including their larger branches on a two year basis. The examination process is comprehensive and covers a wide range of banking areas, including risk management systems, internal controls, management systems, compliance with prudential requirements, and asset quality and provisioning. A comprehensive system of off-site monitoring of banks is based on the analysis of a wide range of information provided to the CBM by banks on a daily, weekly, fortnightly, monthly and quarterly basis. The CBM examiners are well versed in the various operations of a banking institution; their expertise is adequate. However, some focused training in specialized areas, such as market risks, and risk management processes should be considered for the junior staff. The CBM bank supervisors lack the support of an IT examiner who can assist the on-site and off-site supervisors in their assessment of the reliability and accuracy of a financial information submitted by the banks.

\section{f) Consolidated supervision (CP 20)}

69. Although at present there is no banking or financial groups in Montenegro, the CBM has already introduced regulations which will allow it to comply fully with the international standards for supervising banking groups on a consolidated basis.

\section{g) Accounting standards (CP 21)}

70. Accounting standards for banks are almost completely compliant with this core principle. The new Law of Banks should, however, place specific legal responsibility on a bank's managing board for the maintenance by the bank of comprehensive and reliable accounting records and for the accuracy of the information submitted in its supervisory 
reports. The CBM should also clarify its guidance to banks on the accounting methods which they are required to use in the preparation of supervisory reports. ${ }^{13}$

\section{h) Remedial measures (CP 22)}

71. The CBM's powers to oblige banks formally to take remedial measures in a timely manner, and to close banks, are largely compliant. The CBM has used its formal enforcement powers on several occasions and has been successfully challenged in one case only. This was a case in which the CBM had placed a bank in interim administration, following the application of remedial measures under one article only, of the two separate articles in the LOB which permit such measures. The new Law of Banks should provide greater flexibility to the CBM to impose appropriate remedial measures in individual situations. The CBM should also have the authority to levy fines directly on the banks.

\section{i) Cross-border banking (CPs 23-25)}

72. At present no bank incorporated in Montenegro has established a branch or subsidiary in a foreign country. On the other hand, three major banks in Montenegro are subsidiaries of foreign banks. In one case the CBM has a formal agreement with the home country supervisor which provides for exchanges of information and joint examinations of the foreign-owned bank in Montenegro. In the other case the CBM is keen to negotiate similar agreements with the home supervisors: without such agreement it cannot exchange confidential information and comply fully with CP 25.

Table 5. Recommended Action Plan to Improve Compliance of the Basel Core Principles

\begin{tabular}{|l|l|}
\hline \multicolumn{1}{|c|}{ Reference Principle } & \multicolumn{1}{c|}{ Recommended Action } \\
\hline CP 1(2) Autonomy and Resources & $\begin{array}{l}\text { The CBM should keep supervisors' remuneration broadly } \\
\text { competitive with that offered by commercial banks. }\end{array}$ \\
\hline CP 1(5) Legal Protection & $\begin{array}{l}\text { The CBM, its Council, employees and agents should have } \\
\text { legal protection for actions taken while discharging their } \\
\text { supervisory duties in good faith. }\end{array}$ \\
\hline CP 1(6) Information sharing & $\begin{array}{l}\text { The new Law of Banks should contain clear provisions } \\
\text { regarding confidential information and the circumstances } \\
\text { ("gateways") in which it may be disclosed. }\end{array}$ \\
\hline CP 3 Licensing & $\begin{array}{l}\text { The new Law of Banks should apply the same standards of } \\
\text { personal integrity to managers in banks persons as those } \\
\text { proposed for board members. }\end{array}$ \\
\hline
\end{tabular}

\footnotetext{
${ }^{13}$ The CBM confirms that banks prepare their supervisory reports in accordance with IAS (although the regulation on reporting does not specify the accounting methods to be used).
} 


\begin{tabular}{|c|c|}
\hline Reference Principle & Recommended Action \\
\hline CP 6 Capital Adequacy & $\begin{array}{l}\text { The CBM should define more clearly those general } \\
\text { reserves of banks which are eligible o be included in Tier } 2 \\
\text { capital. }\end{array}$ \\
\hline CP 8 Loan Evaluation & $\begin{array}{l}\text { Past due loans of } 30 \text { to } 90 \text { days should not be considered } \\
\text { as Special Mention credits. Such credits should be } \\
\text { classified as Substandard. }\end{array}$ \\
\hline CP 14 Internal Audit and Controls & $\begin{array}{l}\text { CBM should recommend to banks to increase the staff and } \\
\text { quality of internal auditors. }\end{array}$ \\
\hline CP 20 Consolidated Supervision & $\begin{array}{l}\text { The CBM is recommended to review the formats for } \\
\text { reports which will be submitted by the banks on a } \\
\text { consolidated basis. }\end{array}$ \\
\hline \multirow[t]{2}{*}{ CP 21 Accounting Standards } & $\begin{array}{l}\text { The new Law of Banks should provide that the managing } \\
\text { board of a bank is legally responsible to the CBM for the } \\
\text { maintenance by the bank of comprehensive and reliable } \\
\text { accounting records, and for the accuracy of the information } \\
\text { submitted in its supervisory reports. }\end{array}$ \\
\hline & $\begin{array}{l}\text { The CBM should give clear guidance to banks on the } \\
\text { accounting methods to be used in the preparation of } \\
\text { supervisory reports. }\end{array}$ \\
\hline \multirow[t]{2}{*}{ CP 22 Remedial Measures } & $\begin{array}{l}\text { The new Law of Banks should simplify/clarify the } \\
\text { situations in which the CBM is entitled to place a bank in } \\
\text { interim administration. }\end{array}$ \\
\hline & $\begin{array}{l}\text { The new Law of Banks should empower the CBM to levy } \\
\text { fines directly on the banks. }\end{array}$ \\
\hline $\begin{array}{l}\text { CP } 25 \text { Supervision of Foreign Banks' } \\
\text { establishments }\end{array}$ & $\begin{array}{l}\text { The CBM should continue its efforts to negotiate co- } \\
\text { operation agreements with home country supervisors. }\end{array}$ \\
\hline
\end{tabular}

\section{Authorities' response}

73. The authorities were in broad agreement with its findings, but underlined that considerable progress has recently been achieved in the area of internal controls, including during on-site examinations that uncovered areas of weaknesses in banks. The CBM has paid special attention to the strengthening of regulation and supervision of internal control systems and internal audit in banks, bearing in mind the significance of this area for safe and sound banking operations. The Decision on Internal Controls Systems and Internal Audit in Banks, adopted in December 2003, has been significantly strengthened in relation to the previous one. Moreover, during inspections, special attention has been paid to the adequacy of internal audit in banks, and recommendations for improvement, as well as statements on violation of regulations, have been included in the more detailed and sophisticated inspection reports and have represented a base for preparation of measures against banks. The proposed new Law on Banks pays special attention to the strengthening of 
bank corporate governance, risk management systems, and internal audit. In addition, along with the Bank of Slovenia, the CBM is organizing a seminar for banks to discuss these topics. The CBM continues to enhance its work in this area.

74. Concerning the point on legal protection of supervisors, the authorities pointed out that despite considerable counter-arguments put forward by the CBM, the Constitutional Court has ruled that this provision was unconstitutional.

75. In addition, the authorities pointed out that in practice, examiners require more severe classification than is the classification in category B (special mention) if the loan is past due more than 30 days. Thus, through the examination process banks apply Basel minimal standards. Moreover, it is planned, upon the adoption of the new Law on Banks, to adopt new decision on capital adequacy that would move classification of all asset items to the implementation of the standardized approach of Basel II. 


\section{APPENDiX II: FinanCial SECTOR OVERVIEW}

\section{Structure of the banking system}

76. There are currently ten banks in the country, the largest of which, CKB, was purchased by the Hungarian banking group OTP at end-2006. As a result of aggressive growth (assets more than doubled in the 12-month period ending in June 2007), this bank holds 36 percent of assets, 35 percent of loans (up 120 percent in the 12-month period to June 2007), and 40 percent of deposits as of end-June 2007; however, it accounts for only 19 percent of total banking sector capital. The largest three banks represent 63 percent of total assets. A new bank license was issued in December 2005, and this bank started operating in March 2006. Two operating banks are currently under a supervisory plan. Several bank takeovers have taken place recently: in 2005, Podgorica Bank was purchased by Société Générale (France), and Euromarket Bank was purchased by Nova Ljubljanska Bank (NLB) Montenegro Bank; in 2006, Atlasmont Bank purchased a stake in Pljevaljska Bank, which was renamed Invest Bank Montenegro; OTP purchased CKB, and the state sold 30 percent in Niksicka Bank (renamed Prva_-or First_-Bank) to a former shareholder in CKB. A number of banks have been liquidated — one bank is still in the final stages of liquidation (Ekos Bank).

77. Banks have grown rapidly over the last few years, with declining capital and liquidity indicators. Deposits and loans increased sharply (by 149 and 169 percent respectively) in the 12-month period ending in June 2007. ${ }^{14}$ Capital adequacy for the system stood at 18.7 percent as of end-June 2007 with a significant dispersion across banks, ranging from 14 percent to 169 percent. Bank profitability appears rather low, with return on assets falling from 2.5 percent in June 2005 to 1.4 percent at end-June 2007 for the banking system as a whole. The net interest margin declined from 6.9 percent in December 2004 to 1.8 percent at end-June 2007 as a result of increased competition in the context of high operating and regulatory costs. Nonperforming loans (NPLs) have fallen to 2 percent of total loans, with provisions of 104 percent of NPLs.

78. Provisions have fallen as a percentage of total loans (see Table 3 ). The loan-todeposit ratio is at 95 percent at end-June 2007, up from 77 percent in December 2005, due to the strong growth of loans. Liquidity - quite seasonal- has declined, with liquid assets falling to 25 percent of total assets at end-June 2007. There is some lengthening of maturities, more pronounced on the assets than on the liabilities side.

79. Privatization of banks has substantially progressed, but the state continues to hold minority shares in five banks, for a total of 4 percent of the banking system at end2006. The state (Ministry of Finance, the Employment Agency of Montenegro and the

\footnotetext{
${ }^{14}$ Property-related lending represented 45 percent of consumer loans in December 2006, of which 9 percent mortgage, 20.5 percent residential, and 15.5 percent reconstruction loans.
} 
Development Fund) recently sold a stake in Niksicka Bank (30 percent), but the state continues to own over 14 percent of the bank after that transaction. ${ }^{15}$

80. Foreign banks have a large presence in Montenegro, but not all foreign-owned banks have first-tier parent institutions. CKB, NLB Montenegro Bank, Podgoricka Bank, and Hypo-Alpe-Adria Bank have rated parent institutions - the other majority foreign-owned banks may have more limited access to know-how, capital, and liquidity. ${ }^{1617}$

81. Concentration risk is high, both on the asset and liability sides. Banks' net exposure to the 30 largest debtors amounted to 16 percent of loans at end-June 2006. The largest 20 depositors in each bank range from 21 percent of deposits in the least exposed bank to 91 percent in the most exposed bank; the 20 largest depositors in all banks account for 36 percent of all deposits.

\section{Nonbank financial sector}

\section{The non-bank financial institutions sector (NBFIs) represents in total about} 16 percent of GDP at end-2006. Insurance and leasing companies are regulated by the Ministry of Finance, micro-finance providers by the CBM and capital markets by the SEC. The NBFIs have experienced substantial growth in the past couple years, although at rates well below bank assets, and a number of (mostly foreign) market participants have entered the market.

83. The insurance sector, with EUR 31 million of assets at end-2005 remains small, though premiums grew 22 percent in 2005. Five insurance companies and one domestic reinsurance company are currently in operation, providing property, casualty (or accident), life and motor third-party liability (MTPL) insurance. Risk exposures are concentrated amongst two insurers, Lovcen and Montenegro Insurance, which together received more than 90 percent of all premiums in 2005. Two newer small insurers are fully foreign owned and Lovcen, the dominant market player, is majority-owned by foreign interests. About one-half of all insurance premiums invoiced in 2005 were for MTPL, with life insurance representing the smallest amount, less than 3 percent of total invoiced premiums. Total reported assets are

\footnotetext{
${ }^{15}$ Other shares are held in Invest Bank Montenegro (13 percent), Podgoricka Bank (6 percent), Hipotekarna Bank (3 percent), and NLB Montenegro Bank (2 percent).

${ }^{16}$ Second largest NLB Montenegro Banka is majority-owned by Nova Ljubljanska Bank (NLB) from Slovenia. Podgoricka Bank is the third largest bank, purchased in March 2006 by Société Générale. Among the mediumsized banks, Opportunity Bank is entirely foreign-owned, but not by a bank. Komercijalna Bank Budva is a small bank owned by Komercijalna Bank (Serbia). Hipotekarna Banka, historically the leading bank in Montenegro, has close to 70 percent foreign capital, but those shareholders are not a bank. Newly-licensed Hypo-Alpe-Adria Bank is wholly-owned by Austrian Hypo Group Alpe-Adria.

${ }^{17}$ NLB is rated A-/F2 by Fitch Ratings; Société Générale AA/F1+; OTP Bank is rated BBBpi in December 2006 by Standard \& Poor's.
} 
roughly equivalent to the total realized gross 2005 insurance premium of EUR 32 million, which suggests insurers have established small reserves to date. Finally, with only one registered re-insurance provider in the country, Lovcen-Re, all such risks remain with the domestic re-insurer or are transferred to one of several foreign re-insurers.

84. Following the introduction of the Law on Leasing in late 2005, five firms have entered the market, three of which are affiliated with foreign-owned banks. To date, about 500 contracts have been entered into with a total value of EUR 42 million. About twothirds of the contracts issued are financial leases for the purchase of autos and buses. As such, leasing can be seen to provide access to finance for many who would not otherwise be able to afford to buy new vehicles or other equipment. Leasing companies are required to be registered under the Business Organizations law but are not subject to any form of regulation and can thus operate with minimal capital or controls in place. While the leasing industry does not give rise to systemic risk issues, potential operational and/or credit risks may arise in the event that credit extended to bank-owned leasing companies is transferred to the banks' balance sheets. The CBM monitors such exposures.

85. The Law on Micro Credit Financial Institutions, which came into force in 2003, has resulted in the establishment of four micro-finance institutions (MFIs). This sector has grown substantially in three years - as at end-2006 total assets were about EUR 34 million, up from EUR 9 million in June 2003. This sharp growth indicates a continuing strong demand for largely unsecured lending to new micro-entrepreneurs. The CBM licenses and regulates MFIs, providing annual on-site examinations and receiving regular off-site reports. MFIs are not permitted to accept deposits. The established MFIs have accumulated a substantial capital base and longer term source of funding through their successful lending practices. The micro finance industry appears to be operating well and does not give rise to any particular concerns at this stage.

86. The exchange traded part of the capital market consists of nearly $\mathbf{4 5 0}$

companies. In addition, six investment funds (with assets consisting of both domestic and foreign securities and real estate) are traded on the exchange with a turnover of EUR 52 million during 2006, 14 percent of total. There hardly exist domestic institutional investors, pending the creation of pension funds. The bond market is nearly non-existing. Market turnover of all bond issues on the exchanges is EUR 19 million, 5 percent of total turnover.

87. Montenegro has developed a set of modern registry systems that facilitate the assessment and management of financial risks. The registry systems include: (i) register of legal persons maintained in the Commercial Court; (ii) registry of pledges over movable property, also maintained in the Commercial Court; (iii) cadastre or land registry, including mortgage registry, which is maintained and operated by the Agency for Real Estate; and (iv) central securities registry/depository, which is maintained and operated by the Central Depository Agency (CDA). In addition, there is a mandatory collection of credit information in a closed registry system maintained and operated by the CBM. 